\title{
PROG IRES
}

\section{or}

\section{MEDICAI, SCIENCE}

\author{
MEDICINE \\ UNDF:I TIY: cIIAlur: or \\ IY. S. 'IHAYH, M.1).,

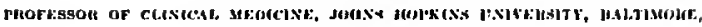 \\ 3].AICIC.S.SI), \\ ANI \\ IROGI:R s. MORHAS, M.D.,

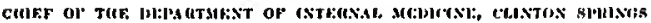

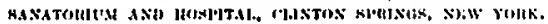

A Contrlbutlon to the Functlonal Dlagnosis of Renal Dlsease.-

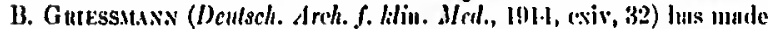
exict studies of the excretion of water, sodimun chlorite mul uit regen in " sunall series (five) of neploritics. 'Pbe patients were placed in $\|$ diet of riee, eondensed milk, and rasplocrry juire. 'The aliet was mulyoul

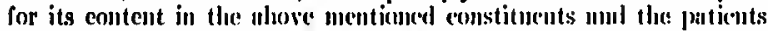

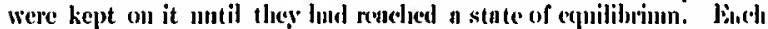
experiment was divided into fanr periods: (1) T'le prediuminary periad in which the patient was kept on $n$ unilk or inilk-rice dict until there: was equilihrinum in nitrogen, sodium chloride, mud water. (2) 1)nring

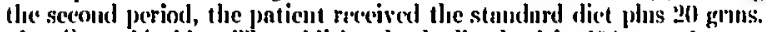

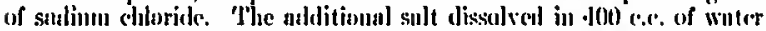
wus given only an the lirst day of alus period. (3) In the third perin:d, one or two liters of water were arleded to the" stumdurd diet. Jhe cextra water wirs alse given ouly on the first day of the provioul. (1) In the fourth period, the patient received the stindard diat plus 20 grous. of Iren dissulved in 250 e.e. af water given on the first day. 'Two of the patients laal markedly cantracted sclerntic kidneys, as mutops. proverl. 'l'wo sullered from arteriosclerotie remal clmoges, while the lifth lad (dironie glomernlo-mepluritis. The elanges in water exoretion were the least notiecable. Defect in the excretion of soalium chloriale wiss fommd in all of the enses, being especinlly marked in one of the cases of interstitial nephritis. In the other enses there was a moderate chelay. in exeretion. 'llie uren exeretion wis studied in only three ensis. if marked deluy was noted in one of these ulso, 1 pitionit with contiocted kidacy. 'Jlac exporiments slıow, Griessumum suy:s, that IIs a molo dis-

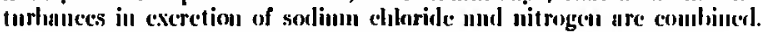
vol. 149, wo. t.-JANuthY, 1915. 
Nevertheless, there are enses in which the disturbance of function elicfly affects only the salt or the uren. Thus the elissifiention of renal diseases on the basis of exeretion of sult and uren (Wiclal, Mïller) secms justifiable.

Factors Concerning the Coagulation of Blood.-CAnsos, MFx-

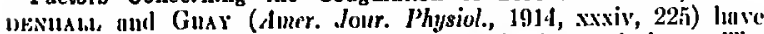
devisel a graphic methorl for the study of hlood congulation. 'T'he instrmment consists of a light almminmm lever with a long arm, on the enI of which is a writing pen which moves over a smoked armon. On the shorter arm there is placed u pice of line copper wire 8 cm. in length. This wire extouls inta a commin. In ull the experinents a constant temperature of $25^{\circ}$ ( $:$ was unintuined, and eammule of the same size were always nserl. This insured the tuking of the sane amonnts of bloml. Tliey were alble to show that the intruvenoms injections of small closes of idrentalin, or subentuncons closes of larger size, given to

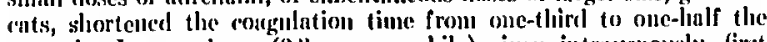
normal. Iarger doses (0.3 mg. por kila) fiven intruvenonsly, (irst slowed and then lastened blond eoagulation. 'I'he effect noon congula-

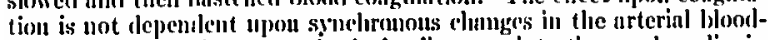
pressure. After the removial of the liver or intestines, adrenaliu in small doses couses no liastening of eongulation, eveu when adled to the witludiwl bloot. 'llase experiments were unale in an attempt to (wplain the livpothesis that the liver or intestines, or lootli, are aroused hy alremalin to grester netivity, sts II result of which one or more of the fnetors concerned in congulation are relonsed. Stimulation of the splanelmies in auestlotized ents aceelerutes the congulation tiune very promptly. 'I'he effect wears off in from ten to thirty mimntes, and is less markel when the experiment is repenterl. If the udrenal glamil on the side of stimnlation is first removerl, no acederation of eongulation was observel. Hence the assinuption that the hasteving is dine to the release of sonic eomponent of the adreual glancl. In a similar way, the: irritation of large nerve trumk, or a large operation performed under liglit anesthesia, gives n murked increase in the rupidity of enagulation. Sintes of emotion eanse the same in less than one-linlf uimute. Cammon, Menlenlaall and (iroy, assime that in states of pain or cmotion the increased rapidity of the congulation time is the result of an increased out tuut of adreualiu.

Blood Findings in Some Psychoses.-ITTEx (Zcit. f. d. gcs. Ncurol.

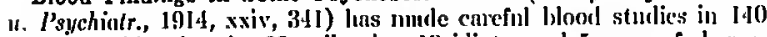

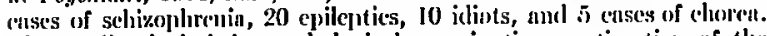
'l'he studies includel morplonlogieal exmminations; estimution of the congulation time aceording lo Burker's method; the resistance of the refl-blood ecls, and the aleterminntion of the specific gravity accordius to Ilmumerselilag's technique. 'The results of lis finlimgs are as follows: In schizoplirenia the red-blood eells are found much incerensed, especinlly in states of entatonia and stupor, probably dne to vatsomotor disturbances. 'The white eells show slight increnses, particularly: in aconte enses and chronic hebephrenies. Nentropliale lenliogetes aro the ones inereased, but witlo the sulssidence of neoto syouptoms there is a temelency for the development of a lympluneytosis. Tlhis contiunc's 